\title{
„Środkowoeuropejskość mierzy się z jądrem ciemności”. Z Krzysztofem Czyżewskim rozmawia Magdalena Brodacka
}

\section{“Central European Encounters with the Heart of Darkness.” Krzysztof Czyżewski in Conversation with Magdalena Brodacka}

Magdalena Brodacka: Rozmawiamy w dniu zakończenia 7. edycji Festiwalu im. Jana Błońskiego organizowanego na Wydziale Polonistyki Uniwersytetu Jagiellońskiego w Krakowie. Tym razem motywem przewodnim festiwalu były "Głosy ze środka Europy”, a Pan brał udział w dyskusji o tytule „Europa Środkowa w nowym wydaniu”. Uczestnicy rozmowy spierali się o trwałość mitu środkowoeuropejskiego dzisiaj. Zastanawiam się nad potrzebą dyskusji o idei czy też micie środkowoeuropejskim, skoro napotykamy trudności już w trakcie jego definiowania. Czy idea Europy Środkowej jest współczesnemu Polakowi i Europejczykowi jeszcze potrzebna?

Krzysztof Czyżewski: Myślę o kilku wymiarach trwałości idei Europy Środkowej w dzisiejszym świecie. Z jednej strony rozumiem środkowoeuropejskość jako próbę wejścia w miejsca i przestrzenie, które ciągle nie są przez nas w całości zagospodarowane. Dzieje się tak z różnych powodów, między innymi dlatego, że historia tych miejsc była w dużej mierze przemilczana, zakłamana czy peryferyjna. Taka, której się troszkę wstydzono, z której łatwo się uciekało i wyjeżdżało. Chodzi o takie zagospodarowanie miejsca, które obejmowałoby wszystko, co zostało odrzucone, przeinaczone, wszystko, co boli, co nie jest takie, jak gdzie indziej, nie błyszczy tak, jak kultura pop, czy nie wygląda tak, jak na Zachodzie. Chodzi o dostrzeżenie w tym skarbu, który ma potencjał duchowy i tajemnicę. Cały czas wydaje mi się to niezwykle fascynujące i pionierskie, niezależnie od liczby działań podejmowanych w związku z tematyką środkowoeuropejską. Sam jestem wydawcą literatury środkowoeuropejskiej i współprowadzę ośrodek „Pogranicze - sztuk, kultur, narodów”. Dzięki temu widzę, jak wiele jest białych plam i jeszcze niezagospodarowanych połaci. To jest fascynująca przygoda odkrywania nowych nazwisk czy korespondencji, na przykład tej między zupełnie u nas nieznanym Maxem Blecherem i Brunonem Schulzem. To stawia tamę próbie ucieczki od tych miejsc, które zamieszkujemy. Mam zresztą poczucie, że krytyka i rodzaj dezynwoltury, z którą 
traktowano mit środkowoeuropejski wynikały z kompleksów, braku dojrzałości i odwagi, żeby się z nim zmierzyć. Czasem łatwiej jest się po prostu oderwać od tego, co trudne i uciec. To jest jak z sąsiadami - gdy są za blisko, to wtedy człowiek szuka wolności w tym, co jest nieznane i dalekie, lecz nie da się zdobywać obywatelstwa światowego, jeśli nie oswoi się najbliższego sąsiedztwa. To jest właśnie ta najtrudniejsza droga budowania środkowoeuropejskości. Kiedyś pisałem o tym, jak łatwo jest być Europejczykiem w Sejnach, a jak trudno być tam Środkowoeuropejczykiem. W szkolnych programach mamy twórczość Goethego, Szekspira i Bacha, a w dalszym ciągu nie mamy Morisa Rosenfelda czy wojny polsko-litewskiej. I jesteśmy ciągle od tego odcięci, ponieważ trzeba włożyć spory wysiłek w przepracowanie tych wydarzeń, a przy tym przełamać swoje uprzedzenia i zabliźnić rany, którymi pogranicze jest podzielone. Jeżeli się tym nie zajmiemy, jeżeli uciekniemy od Europy Środkowej, to pozwolimy w tę przestrzeń wlać różne skrajne ideologie. Jeśli przykładowo nie zagospodarujemy dramatu wojny polsko-litewskiej, to wtedy na miejsce pracy odbudowującej sąsiedzkie współistnienie wejdą bardziej radykalne scenariusze: narracje nacjonalistyczne, które separują jednych od drugich. Opowieść środkowoeuropejska jest opowieścią o pełnym sąsiedztwie i wielokulturowej tradycji. Jestem świadom, że taką narrację można łatwo wyidealizować, a przecież Pierwsza Rzeczpospolita, unia polsko-litewska, czy Wielkie Księstwo Litewskie nie były rajem na ziemi. Jednak krytyczne spojrzenie na wspólne dzieje nie wyklucza refleksji i odkrywania, ile zostało wspólnie zbudowane, jaki palimpsest kulturowy jednak się na tych ziemiach wytworzył. Jest to tradycja tragiczna, ze szczyptą bólu i miłości w każdym okruchu losu, której nie sposób zignorować. Jeżeli się ją wyeliminuje, jeżeli odbierze się nam opowieść jagiellońską, opowieść środkowoeuropejską, to wtedy pozostaje niebezpieczna pustka. A w pustkę wchodzą wykluczające się, wrogie, konfrontacyjne ideologie nacjonalistyczne. Niebezpieczeństwo tego widzę też dzisiaj. Jestem ciekaw, jaką alternatywną opowieść stworzy młode pokolenie wobec narastających murów, podziałów i nacjonalizmu. Będą to przecież nowe mapowania, nowe nazwiska, nowe teksty i nowe odczytania środkowoeuropejskości.

Często spotykam się też z rodzajem idealizacji; sprawia to wrażenie, jakbyśmy za pomocą mitu środkowoeuropejskiego chcieli powiedzieć sobie i światu, że panowały tu kiedyś piękna wielokulturowość, zgodne współistnienie różnych narodów. A to przecież można łatwo zdyskredytować, przywołując doświadczenia, które przyniosła ze sobą okrutna historia i konflikty, które miały tu miejsce. Wszystko, co powstało najwspanialszego w Europie Środkowej: filozofia dialogu, teatr śmierci Tadeusza Kantora, twórczość Czesława Miłosza czy Danila Kiša, to dzieła zrodzone na popiołach i w jądrze ciemności. I to nie są żadne tanie utopie, lecz konkretne propozycje wyjścia z jądra ciemności czy z Ziemi Ulro, gdyby mówić językiem Miłosza. A najbardziej niezwykłe jest to, że odpowiedzią na takie tragedie nie jest całkowita ucieczka w nihilizm albo abstrakcję, lecz próby budowania konstruktywnej opowieści, jak Świat poema 
naiwne pisane w trakcie drugiej wojny światowej czy dzieło Kiša, które przepracowuje rozszalały nacjonalizm na Bałkanach. Środkoweuropejskość mierzy się z prawdziwym piekłem, mierzy się z jądrem ciemności.

M.B.: Mówi Pan o potrzebie tworzenia narracji tożsamościowotwórczej, życiodajnej. Zastanawiam się, czy Europa Środkowa już przepracowała wojny i doświadczenie komunizmu, czy ma świadomość bagażu dwudziestowiecznej historii na początku wieku XXI. Jak środkowoeuropejskość wyraża się dzisiaj? Czy młode pokolenie może w ogóle taką narrację wypracować? Bo przecież będzie się ona zdecydowanie różniła od tej z drugiej połowy ubiegłego stulecia. I chciałabym wziąć w nawias narracje definiujące Europę Środkową sensu stricto, ale zastanowić się nad opowieściami, które są Europą Środkową, czyli wyrażają jej istotę.

K.C.: Z jednej strony mamy do czynienia z aktualnością etosu środkowoeuropejskiego w wymiarze międzynarodowym czy nawet globalnym, ponieważ to, co było dramatem, z którym musiała się zmierzyć wielokulturowa, podzielona nowymi granicami Europa Środkowa, staje się rzeczywistością współczesnego świata. Gdybyśmy na przykład wzięli pogranicze jako model środkowoeuropejski, to okazuje się, że jest w nim coś zaskakująco silnie rezonującego z dniem dzisiejszym. Już w samym pojęciu skrywa się trudność w jego właściwym rozumieniu. Na język angielski pogranicze tłumaczy się często jako bordeline, a nie borderland. Chodzi o wyjaśnienie różnicy, że nie jest to przestrzeń oddzielona sztywnymi granicami, że żyją na niej bardzo różni ludzie, a granice przebiegają wewnątrz. To jest aktualny model życia, bo przecież pogranicza spotykamy dzisiaj w Barcelonie, Zurychu i Londynie. Ja sam siebie określam mianem pokolenia Bośni, bo to wojna w byłej Jugosławii była dla mojej generacji wtajemniczeniem w dramat pogranicza. Z Sarajewa spoglądaliśmy na Europę inaczej niż z Warszawy czy z Berlina. I już wówczas wiedzieliśmy, że to nie jest marginalny konflikt bałkański, lecz że z biegiem czasu takie same doświadczenia przyjdą do społeczeństw Zachodu i tak będzie wyglądała rzeczywistość młodego pokolenia, któremu przyjdzie żyć w świecie wewnętrznych granic, w świecie pogranicza. Nie da się od tej rzeczywistości uciec.

Jak zbudować swoją obecność i opowieść w takim świecie? Czytana dzisiaj przeze mnie ze studentami na Uniwersytecie Bolońskim Rodzinna Europa jest dla młodego pokolenia książką niezwykle współczesną, zwłaszcza ze względu na integrację europejską rozumianą jako projekt kulturowy, nie tylko gospodarczo-polityczny. Bardzo ważna dla współczesnej opowieści środkowoeuropejskiej jest Ukraina. „Herezja pogranicza” - tak nazywało się spotkanie w Charkowie, w którym uczestniczyłem razem z Serhijem Żadanem. Powiedział mi wtedy, że tamto pogranicze ukraińsko-rosyjskie nie ma literatury przypominającej twórczość Miłosza czy Kiša, że nie ma kultury tworzącej wspólną opowieść. Czy to jest problem? Na pewno jest to szansa na powstanie rzeczy nowatorskich. 
Oczywiście ogromną rolę gra tutaj kontekst: Żadan musiałby taką opowieść tworzyć podczas wojny ukraińsko-rosyjskiej, a to jest bardzo trudne. Gdybym ja żył w trakcie konfliktu polsko-litewskiego, to nie wiem, czy tworzyłbym w Sejnach ośrodek „Pogranicze”, czy raczej wziął się do walki. To są sytuacje, które jeszcze bardziej wyostrzają dramatyzm i pytanie o wspólną opowieść dla obszaru, który jest w sytuacji wojny. Z drugiej strony zdajemy sobie sprawę, że zaporę tej wojnie może położyć coś, co jednak jest alternatywne dla takiej ostrej, nacjonalistycznej retoryki, że to nie jest konflikt, który rozwiąże się tylko militarnie. Że jest to również walka kulturowa - o światopogląd, o mentalność, o opowieść, która może stworzyć alternatywę dla szowinistycznego populizmu rodzącego się po obu stronach. Podaję przykład rosyjsko-ukraiński, gdzie pojawia się ekstremalna potrzeba budowania opowieści środkowoeuropejskiego pogranicza, bo bez niej będzie to konflikt nierozstrzygalny. Ale taka sama potrzeba istnieje w miastach, do których przybywają dzisiaj emigranci.

M.B.: Potrzeba przepracowywania konfliktów wydaje się oczywista w miejscach pogranicza, ale czy jest ona jeszcze zauważalna w takich miastach jak Warszawa czy Praga?

K.C.: Tak, mam poczucie, że coraz więcej pracy dla mnie i dla zespołu „Pogranicze" jest we współczesnych metropoliach. Coraz częściej pracujemy w Gdańsku, Lublinie, Amsterdamie, Barcelonie, Birmingham czy Nowym Jorku. Pojawiła się także naturalna potrzeba wpisania perspektywy środkowoeuropejskiej w programy nauczania na uniwersytecie, w coraz większym stopniu otwarte na interdyscyplinarność. Tam, gdzie uczę na Uniwersytecie Bolońskim, na wydziale political science, pogranicze rozumiane było wyłącznie jako strefa konfliktu. Tradycje kulturowej polifonii, ludzie pogranicza czy filozofia dialogu nie miały tam swojego miejsca. Wokół pogranicza stworzył się język wykluczający, język rozdzielający i analizujący konflikty, utrwalający podziały, w tym na mniejszości narodowe czy odrębne kultury. Tymczasem dla moich studentów bardzo trudne, ale i odkrywcze okazuje się operowanie językiem nazywającym to, co wspólne, i obejmującym procesy odradzających się więzi wspólnotowych. Ich prace semestralne czy magisterskie często poświęcone są sylwetkom środkowoeuropejskich „budowniczych mostów” bądź tradycjom dialogu w naszym regionie. To jest bardzo trudne już na poziomie samego języka. Nie może być on tani ani naiwny i propagatorski, trzeba znaleźć środki wyrazu, które ukażą całą złożoność takich zjawisk. Dużo łatwiej jest nam operować językiem krytycznym bądź negatywnym, tym bardziej że jest on silnie umocowany w tragicznej historii „skrwawionych ziem”, a także w bogatym warsztacie naukowym. Nie da się jednak tym językiem wyrazić całej prawdy o pograniczu. Wiele w tym względzie nauczyło mnie doświadczenie pracy ze społecznościami lokalnymi środkowoeuropejskich pograniczy: język, którym operują ich mieszkańcy, światy, możliwości wyrazu wewnętrznych emocji i ustanawiania międzyludzkich 
relacji dotyczą prawie wyłącznie tego, jak okazać swój ból i jak odróżnić się od drugiego. Są one natomiast bezradne w wykonaniu gestu ku porozumieniu, spotkania się w jednej przestrzeni, potrzebie powrotu do wspólnej opowieści. A przecież taka potrzeba istnieje, tak samo jak świadomość, że zamieszkiwanie poszczególnych dzielnic miasta nie jest tożsame $\mathrm{z}$ byciem $\mathrm{u}$ siebie $\mathrm{w}$ jego centrum. Brakuje nam i języka i przestrzeni do bycia razem z innymi w obrębie jednej społeczności, bo tym właśnie jest pogranicze. Od kilku lat w rocznym kalendarzu „Pogranicza” pojawiło się wydarzenie „Misterium Mostu”, organizowane w Krasnogrudzie każdego 22 sierpnia. Ma ono charakter widowiska teatralno-muzycznego, przygotowywanego przez mieszkańców i gości ze świata, w centrum którego znajduje się dramat zerwanego mostu i próba jego odbudowywania. Dzięki temu wydarzeniu pojawiała się okazja do wspólnego świętowania ludzi różnych kultur w przestrzeni sacrum. To nie to samo, co zapraszanie dla przykładu katolików na święta prawosławne przez ich sąsiadów, bo towarzyszy temu poczucie, że jest się na nich tylko gościem. A Święto Mostu jest takim szczególnym czasem, w którym każdy człowiek czuje się u siebie. Otóż wydaje mi się, że to jest coś bardzo nowoczesnego, nigdy wcześniej nic takiego nie istniało, nie było „Misterium Mostu”, tak jak i wielu innych form budowania „tkanki łącznej” praktykowanych w „Pograniczu”. To nie jest odgrzewanie starych idei czy powracanie do anachronicznych tradycji, lecz wytwarzanie odważnych, awangardowych form wyrazu tego, co środkowoeuropejskie. W tym widzę siłę i żywotność Europy Środkowej dzisiaj.

M.B.: Podkreśla Pan jednak nieustannie, że całe bogactwo pracy twórczej, potencjał krytyczny i analityczny są niezbędne, ale zaraz za nimi powinno iść konkretne działanie. To jednak wydaje się najtrudniejsze. Kreatywne myślenie i podejmowanie praktycznej aktywności wymaga nie lada odwagi i pewnej emocjonalnej samoświadomości. Mówi Pan o budowaniu mostów, o tkance łącznej w miejscach i wśród ludzi, którzy są świadomi takiej potrzeby i wiedzą, jak ogromnie jest to istotne. Zawsze duże wrażenie robiła na mnie filozofia Jana Patočki, bardzo ważnego filozofa Europy Środkowej, który obrazowo podzielił historię Czech na wielką i małą: mała jest wtedy, gdy zajmujemy się sami sobą, własnym narodem, a wielka wówczas, gdy wychodzimy do innych. Żyjemy w świecie nasilających się konfliktów wewnętrznych w poszczególnych państwach, przybywają do nich emigranci, pojawiają się problemy z tożsamością. Paradoksalnie, zamykamy się w nacjonalistycznych narracjach. Powtarza Pan wielokrotnie, że gdy centrum jest mocne - silny środek, to granice już nie muszą być tak wyraźnie zarysowane. Dziś potrzeba budowania mostów jest ogromna, może większa niż kiedykolwiek wcześniej, a z drugiej strony mamy do czynienia z narracjami, które są zamykające.

K.C.: Zgadzam się, i te narracje wydają się tak potężne, że wymuszają na nas myślenie o tym, że albo stworzymy opowieści równie mocne, albo wszystko 
inne nie ma sensu. Takie myślenie jest moim zdaniem bardzo niebezpieczne. Piszę o tym w Matym centrum świata: najgroźniejsza jest dziś wiara, że tego Goliata może pokonać tylko drugi Goliat, a to jest pułapka. Goliat z drugim Goliatem przecież sobie poradzi, ale boi się małego Dawida. Brakuje nam dzisiaj wiary w to, co małe, w sens małych kroków, budowania rzeczy wielkich w najbliższym sąsiedztwie, za które możemy brać odpowiedzialność. To jest moja koncepcja stawiania oporu tej fali nacjonalistycznej czy konfrontacyjnej narracji, o której Pani mówi. To znaczy polifonia małych centrów świata, które nie roszczą sobie pretensji do monopolu na wiedzę ani na władzę nad innymi; które nie dążą do zagarnięcia ani wchłonięcia mniejszego lub słabszego, lecz są silne siłą innych małych centrów świata; które zakorzeniają nas w świecie i poprzez to otwierają. Dla mnie ten obraz, o którym Pani mówi, to był chyba rok 2015, rok szczytu Grupy Wyszehradzkiej: pamiętam ponurą fotografię, a na niej czterech przywódców państw wyszehradzkich, którzy ze smutnymi minami mówią, że nie chcą u siebie imigrantów. To jest dla mnie bardzo ważna cezura w Europie Środkowej, obraz ten wyraża, jak słabi jesteśmy, jak zalęknieni, jakimi zasiekami oplecione są nie tylko nasze granice, ale i nasze rozumienie tożsamości, jak słabe są nasze centra. Gdy przyjeżdżają do nas ludzie z rozdartych wojnami pograniczy, takie jak palestyńsko-izraelskie, i słyszą o budowaniu mostów, podchodzą do tego bardzo sceptycznie, mówiąc, że nic z tego nie będzie. I rzeczywiście, gdyby od razu zmierzyć się z rozstrzygnięciami na wielką skalę, to okażą się one niewykonalne. Ważne, aby rozpocząć działanie, skierować uwagę na zrobienie pierwszego kroku, wykonanie czegoś konkretnego, małego. I wtedy niemożliwe rzeczy nagle stają się możliwe.

Moje doświadczenie budowania mostu jest bardzo osobiste. Kiedy byłem jeszcze małym chłopcem, mieliśmy łąkę przy domu. Był tam niewielki strumyk, który wtedy wydawał mi się olbrzymią rzeką i bardzo bałem się przejść na drugą stronę. Wówczas mama nauczyła mnie takiego sposobu: połóż pierwszy kamień i stań na nim. Podawała mi kolejne kamienie, żebym je ułożył. Kiedy stanąłem na trzecim kamieniu i byłem już na środku, łatwiej było już dojść do drugiego brzegu niż zawrócić. To jest filozofia budowania mostów; staram się ją dawać w odpowiedzi na lęki, które czujemy, na zagrożenia bezsensem i niewiarą w małe. Nagle z takich konkretnych działań może urodzić się siła, wiara w siebie, w to, że uda się coś choćby niewielkiego, ale to zawsze posuwa nas do przodu. I nagle okazuje się, że takie działanie ma siłę promieniowania. Tajemnica małych kroków jest niezwykła, bo mogę o tym, co robię na co dzień, rozmawiać teraz z Panią w Krakowie, w Amsterdamie i na całym świecie. Może największa siła tego przekazu nie leży w samej filozofii, lecz w fakcie, że ośrodek „Pogranicze” dalej istnieje, że historia czy rzeczywistość nie zmiotła naszego warsztatu budowania mostów, bo wielu ludzi od dawna uważało, że z tym naszym idealistyczno-utopijnym myśleniem powinno nas już dawno nie być. A przecież swoją pracę opieramy na działaniach w małych kręgach, na bliskim kontakcie z ludźmi i realnością konkretnego miejsca, na inicjatywach rozpisanych 
w długim trwaniu. Dziwimy się czasem, że prowincje owocują niezwykłymi osobowościami i dziełami kultury. Wpływają na to wielojęzyczność i wielokulturowość tych regionów, ale nie tylko, także ich tragiczna historia. Pracując z ludźmi na sejneńskim pograniczu, odkryłem, jak bardzo bolesne i złożone jest ich życiowe doświadczenie. Aby dać wyraz temu doświadczeniu, nie można uciec w płytkie formy pracy kulturalnej czy tanie kompromisy z poziomem artystycznym, bo prawda tego pogranicza jest zbyt wymagająca. Trzeba na przykład fenomenalnej konstrukcji powieści Škvoreckiego o inżynierze ludzkich dusz, żeby w ogóle prawdziwie odnieść się do naszych doświadczeń. Mam poczucie, że w literaturze polskiej nie mamy takiego wymiaru epickiej opowieści o środkowoeuropejskiej ad hominem. Dzisiaj przed młodymi twórcami stoją podobne wyzwania i podobne zagrożenia. A może jeszcze większe, bo rynek wymaga od nich literackiego i kulturowego popu, a to jest tylko ślizganie się po powierzchni. Niepokoi mnie również sprowadzenie Europy Środkowej do skansenu w stylu „nasza chata z kraja” - jesteśmy unikatowi ze swoim cywilizacyjnym zapóźnieniem, duchowo nie zepsuci tak jak Zachód, skąd już blisko do fantomowych wyobrażeń w rodzaju antemurale christianitas. Kupuje to chętnie rynek zachodni, nie tylko krajowy, z lubością przyzwalając na biczowanie Zachodu przez Wschód, nigdy jednak nie zapominając, że to przyzwolenie dotyczy nie równorzędnych partnerów, ale „innej Europy” - Une autre Europe, jak Francuzi przetłumaczyli Rodzinna Europę Miłosza. Powinniśmy być odważni i niekonformistyczni. Musimy znaleźć odpowiedni język do wyrażania prawdy, tak jak robiły to wcześniejsze pokolenia, tak jak zrobił to Miłosz w Zniewolonym umyśle czy Ziemi Ulro, która została ostatnio przetłumaczona na język rosyjski. To zmaganie się Miłosza ze współczesną duchowością może na nowo znaleźć żywy rezonans, tym razem za granicą.

Pokolenie młodych twórców stoi dzisiaj przed nowymi wyzwaniami, formy zniewolenia są mniej oczywiste, trudniej uchwytne. Kleszcze uwarunkowań wolnorynkowych, festiwalizacja życia kulturalnego, medialno-korporacyjne ścieżki kariery - za tym wszystkim kryją się szanse, ale też nowe formy zniewolenia. Byłem przez kilka dobrych lat prezydentem sieci europejskich domów literatury HALMA. Przyjrzałam się, jak funkcjonują centra literatury dla tłumaczy, pisarzy czy programy rezydencyjne. Europa jest nimi gęsto usiana. Obserwowałem dramat pisarzy, którzy po bardzo dobrym debiucie weszli w sieć rezydencji i zależności medialno-rynkowych - z jednej strony zapewnia im to komfort życia i tworzenia, z drugiej odcina od rzeczywistości i zamyka w egocentrycznej kapsule stresu. Stąd zjawisko fantastycznie zapowiadających się debiutów, a potem przez kolejne lata dobrze, czasem bardzo dobrze napisane średnie książki, o krótkim żywocie rynkowej promocji, do których nikt później nie będzie powracał. 
M.B.: W czym upatruje Pan zagrożenia dla literatury środkowoeuropejskiej?

K.C.: Między innymi właśnie w zasysaniu jej twórców przez obieg festiwalowo-rezydencyjny, odcinający ich od materii życia. Moja odpowiedź ponownie kieruje się w stronę małych centrów świata, czyli powracania do żywych kontekstów społecznych, kulturowych, ekologicznych, które pomagają w budowaniu opowieści przekraczającej konformizm popkultury i uwarunkowania rynkowe, niepodlizującej się czytelnikowi, nielękającej się eksperymentować $\mathrm{z}$ formą. Literatura poddana medialności i rynkowi nigdy nie ufa wystarczająco czytelnikowi. Kierując się statystyką, danymi liczbowymi przeliczanymi na zysk fiskalny, zakłada, że jesteśmy głupsi niż w rzeczywistości. I choć jest to analiza zlepiona z półprawd, nieuwzględniająca wielu innych, pozafiskalnych czynników, bezkrytycznie się temu podporządkowuje. W małej społeczności z ambicjami tworzenia centrum świata jest inaczej, nie można już ludźmi w ten sposób manipulować, do głosu dochodzą inne kryteria, związane z dobrym życiem, a nie wysokim kontem w banku.

M.B.: Czy wydawnictwo Pogranicze wpisuje się w tę politykę? Bo poza ogromem narzędzi, które Pan dostarcza, poza działalnością kulturową i wypracowaniem dialogu z drugim człowiekiem, współprowadzi Pan konkretną działalność wydawniczą. Wedle jakiego klucza dobiera Pan autorów?

K.C.: Nasze wydawnictwo jest integralną częścią programu działań Fundacji i Ośrodka „Pogranicze”. W ślad za przyznawanym tytułem Człowieka Pogranicza idą książki Jerzego Ficowskiego, Tomasa Venclovy, Bohdana Osadczuka czy Claudia Magrisa, a w tym roku Ireny Veisaitè. Pamiętamy także o innych ludziach pogranicza, takich jak Zuzanna Ginczanka, Stanisław Vincenz czy Elias Canetti. Ważnym dla nas, ciągle zbyt mało znanym, jest świat literatury jidysz - stąd opowiadania Josifa Burga z Czerniowiec, książka Daniela Kaca o Awromie Suckewerze, moje tłumaczenie Mesjasza z rodu Efraima Mosze Kulbaka czy ostatnio przez nas wydana monografia Joanny Lisek Kol isze. Gtos kobiet w poezji jidysz. W realizowanej przez nas od wielu lat Szkole Pogranicza wykładowcami są często historycy, a książki dwojga z nich zainicjowały nasze serie wydawnicze: „Sąsiedzi” - to oczywiście Jan Tomasz Gross, a potem także Joanna Tokarska-Bakir, Wojciech Tochman czy Szymon Redlich; oraz „Ornamenty historii”, seria zainicjowana książką Timothy'ego Snydera Rekonstrukcja narodów. Polska, Ukraina, Litwa, Biatorus', w której ukazała się właśnie opowieść Joanny Roszak o jeszcze jednym, niezwykle ciekawym człowieku pogranicza Józefie Rotblacie zatytułowana Żuraw z origami. Przywiązuję dużą wagę do publikowania w tym „czasie marnym” współczesnej poezji środkowoeuropejskiej, której prawie w ogóle nie ma w naszych księgarniach i bibliotekach. W serii „Inicjał”, z oryginalną grafiką Wiesława Szumińskiego w numerowanych egzemplarzach, wydajemy - z kilkoma wyjątkami - całe tomiki 
wierszy, w wersji dwujęzycznej w przypadku autorów niepiszących po polsku, a nawet wielojęzycznej, jak to było w Wierszach sejneńskich Tomasa Venclovy (oprócz litewskich oryginałów zamieściliśmy też przekłady na rosyjski i angielski). Nie wyobrażam sobie mapy literatury środkowoeuropejskiej bez wspaniałych wierszy Vladasa Braziūnasa z Wilna, opublikowanych przez nas ostatnio, czy przygotowywanych właśnie do druku wierszy Feridy Duraković z Sarajewa. Prowadzenie wydawniczego programu środkowoeuropejskiego to w ogromnej mierze współpraca z tłumaczami, więcej - pomoc w rozwijaniu ich warsztatu i literackich kontaktów, wspieranie młodego pokolenia tłumaczy z małych języków. Temu między innymi służy organizowany przez nas już od kilku lat w Krasnogrudzie „Sejmik Literacki”, na którym twórczo pracują ze sobą pisarze, tłumacze i krytycy literaccy z Litwy i Polski. Owocem tej pracy są między innymi przekłady poezji Braziunasa autorstwa Agnieszki Rembiałkowskiej. Najważniejszą serią oficyny Pogranicze jest „Meridian”, konsekwentnie starający się zapełniać białe plamy na mapie przekładów na język polski literatury środkowoeuropejskiej - powieści, opowiadań, poezji i eseistyki. Staram się odkrywać ważne, ale dawno już napisane książki (w ubiegłym roku były to przekłady Josefa Škvoreckiego autorstwa Andrzeja Jagodzińskiego: Cud oraz Wszyscy ci wspaniali chtopcy i dziewczyny. Osobista historia czeskiego kina; wcześniej na przykład opowieść Hannah Arendt o Raheli Varnhagen), mało albo zupełnie u nas nieznanych pisarzy zaliczanych przeze mnie do panteonu klasyki środkowoeuropejskiej (Max Blecher, Mihail Sebastian, Gregor von Rezzori, János Pilinszky czy Sándor Márai poeta), a także ważne pisarki i pisarzy współczesności (Daniela Kapitáňowá, Ałbena Stambołowa, Miljenko Jergović, Jurgis Kunčinas czy zmarly niedawno Lajos Grendel). W tym roku „Meridian” połączył Eliasa Canettiego Księgę przeciwko śmierci ze Sroka na szubienicy Alhierda Bacharewicza, białoruskiego pisarza i rockmana, współtwórcę awangardowej grupy poetyckiej Bum-Bam-Lit, oraz nową powieść Stoń z Potudnia gruzińskiego mistrza sztuki opowiadania Arczila Kikodze.

M.B.: Nie mogę powstrzymać się przed zadaniem jeszcze jednego pytania: twórczość którego czeskiego pisarza jest Panu najbliższa?

K.C.: Najbliższy jest mi właśnie Škvorecký i w ogóle tradycja czeska, która potrafi być z jednej strony bezkompromisowa i odważna w spojrzeniu na siebie, a z drugiej nigdy niewykluczająca przez stygmatyzowanie „nie-naszych”, słabszych, zbłąkanych. Polacy pretendują do stania zawsze po stronie prawdy i nieskazitelności, a stąd już blisko do myślenia o sobie jako lepszych, znajdujących się po właściwej stronie - mamy niebezpieczną tendencję do tworzenia podziałów. A Czesi mają autoironię i mówią, że słabości są w każdym z nas. Dla mnie bardzo niebezpieczne jest stygmatyzowanie - nie tylko: „nieprawdziwy Polak”, „wykształciuch” czy „gorszego sortu”, ale także: nacjonalista, antysemita, ksenofob. Jeśli kogoś tak nazwiemy, to już nigdy go nie odzyskamy. Józef Tischner 
by powiedział, że to jest zamykanie ludzi w kryjówkach. A tajemnica polega na tym, żeby pomagać ludziom wychodzić z kryjówek, bo każdy z nas jest w jakieś kryjówce i ma swoje lęki. I z tym Czesi radzą sobie lepiej. 